\title{
Batflies Parasitic on Some Phyllostomid Bats in Southeastern Brazil: Parasitism Rates and Host-parasite Relationships
}

\author{
Carlos A Komeno, Arício X Linhares ${ }^{+}$ \\ Departmento de Parasitologia, Instituto de Biologia, Universidade Estadual de Campinas, Caixa Postal 6109, \\ 13083-970 Campinas, SP, Brasil
}

Ectoparasitic batflies were studied on 12 species of phyllostomid bats, by making 35 nightly collections of bats using mist nets at the "Panga" Ecological Reservation near Uberlândia, State of Minas Gerais, southeastern Brazil, from August 1989 to July 1990. Eleven species of Streblidae and one of Nycteribiidae were collected on 12 species of bats. Prevalence of ectoparasitic flies was lower than those reported by other authors for the New World and may be the result of the lack of caves in the study area, causing bats to roost in less favorable locations, forming smaller colonies. The fly, Trichobius joblingi Wenzel, was found on Carollia perspicillata (Linnaeus), showing preference for adult male bats. This could be explained by the predominance of males in the bat colonies, and by the fact that females rest in isolation during the reproductive period making them less exposed to the parasites. The streblid flies, Aspidoptera falcata Wenzel and Megistopoda proxima (Séguy), were found on Sturnira lilium (Geoffroy). A. falcata occurred mainly on young and adult females, whereas M. proxima did not show any preferences relative to the reproductive condition of the host. Ecological factors are important in determining differential numbers of parasites occurring on the different sexes, ages and reproductive state of the hosts.

Key words: Streblidae - Nycteribiidae - Phyllostomidae - Chiroptera - intensity-prevalence - Brazil

Streblidae and Nycteribiidae (Diptera) are exclusively ectoparasitic on bats, and their species are mostly restricted to one genus or species of host (Ross 1961). Nycteribiidae are largely Palaearctic whereas Streblidae are found mainly in the New World (Marshall 1981). Machado-Allisson (1967) and Fritz (1983) suggest that knowledge of hostparasite relationships in these two families may help clarify taxonomic relationships in the Chiroptera. Fritz (1983) suggested that knowledge of the biology and ecology of batflies could possibly elucidate epidemiological aspects of transmission of bat pathogens. This approach will provide more information on ecological aspects of the relationships between batflies and their hosts belonging to the family Phyllostomidae in southeastern Brazil. The main objectives in this paper are to determine the host-parasite associations between batflies (Streblidae and Nycteribiidae) and the phyllostomid hosts at the "Panga Ecological Reservation" near Uberlândia, State of Minas Gerais,

Work financed in part by Fapesp, grant no. 92/1610-9. ${ }^{+}$Corresponding author. Fax: +55-019-289.3124. E-mail: aricio@turing.unicamp.br

Received 20 April 1998

Accepted 30 November 1998 to evaluate their degree of host specificity, and to assess the differential occurrence of the parasites on different sexes, ages and reproductive stages of hosts.

\section{MATERIALS AND METHODS}

The study was undertaken at the "Panga" ecological reservation, an area of 404 ha located 30 $\mathrm{km}$ south of the city of Uberlândia (19\%11'10"'S and $48^{\circ} 24^{\prime} 35^{\prime \prime} \mathrm{W}$ ) at $800 \mathrm{~m}$ above sea level. The climate of the region has a marked periodicity, with a dry, cool season from May to September and a warm, wet period from October to April. Approximately $90 \%$ of the rains occur during the wet season. The rainfall averages $1150 \mathrm{~mm}$ annually. Temperatures range from a maximum of $28.8^{\circ} \mathrm{C}$ down to $17.3^{\circ} \mathrm{C}$. The vegetation found in $80 \%$ of the area is typical of the Brazilian savanna, known as "cerrado", and the remaining 20\% are gallery forests (Araújo \& Schiavini 1988). Bat collections were carried out on 35 nights from August 1990 to July 1991 during new-moon or quarter-moon periods. Bats were captured using two to four separate mist nets with the bottom placed at approximately $3 \mathrm{~m}$ above the ground. Trapping was done from sunset, usually between 1800 and 1900, to sunrise, between 500 and 600. The nets were checked at $15 \mathrm{~min}$ intervals for captured bats. After being removed from the nets the bats were iden- 
tified to species and sex, and the length of the right forearm was measured. For both sexes, the following ages and reproductive stages were also recorded: juvenile, adult, gravid female, lactating female and scrotal-testes male (Williams 1986). A voucher collection of bats was deposited at the Department of Zoology, Unesp, São José do Rio Preto, SP, Brazil. Ectoparasites were collected with forceps and placed in glass vials with $70 \%$ ethanol. They were identified, sexed, counted and a voucher collection was deposited at the "Museu de História Natural - Campinas State University", Campinas, SP, Brazil. Parasite prevalence, intensity and mean intensity were determined according to Margolis et al. (1982): prevalence $=[(\#$ of parasitized bats) / (total \# of bats)] x 100; intensity $=[(\#$ of ectoparasites $) /(\#$ of bats $)] \times 100$; mean intensity $=(\#$ of ectoparasites $)$ (\# of parasitized bats). These rates were determined for each age and reproductive condition of the host and for all bats captured of that species. To compare rates between male and female hosts, $t$-tests were performed. For each sex, analysis of variance was performed to test for differences among the different stages. Possible associations between parasite species on the same host were tested by determining the Pearson correlation coefficient. Statistical analyses, (t-tests, ANOVAS and correlation analysis) were performed (SAS Institute 1986).

\section{RESULTS}

Two hundred and five bats belonging to 12 species from nine genera of the family Phyllostomidae were captured, as well as 158 streblid flies (six genera and eleven species) and seven nycteribiid flies (one species) (Table I).

Trichobius joblingi Wenzel was the most abundant batfly, and was found on Carollia perspicillata Linnaeus. Parasite prevalences and mean intensities were in general higher for adult male hosts (Tables II, IV). Differences found in parasite intensities (Table III) were marginally significant only when the interaction between host sex and developmental stages was considered $(F=1.46 ; P$ $=0.06$ ). Parasite prevalences among the different ages and reproductive states for each sex of the host were not significantly different. Likewise, no differences were found between sexes of the parasites within the same sex of the host. The parasite mean intensity for male bats was also higher than that for females (Table IV).

Trichobius tiptoni Wenzel was found parasitizing Anoura caudifera (Geoffroy), and all rates were higher for females, with a slight preference

TABLE I

Species of phyllostomid bats and their batflies collected at the "Panga" Ecological Reservation, Uberlândia city, southeastern Brazil, from August 1990 to July 1991

\begin{tabular}{lclcc}
\hline Bat species $^{a}$ & $\begin{array}{c}\text { No. of bats } \\
\text { collected }\end{array}$ & Batfly species & $\begin{array}{c}\text { No. of batflies } \\
\text { colleted }\end{array}$ & $\begin{array}{c}\text { Mean no. of } \\
\text { batfly/host }\end{array}$ \\
\hline Anoura caudifera & 16 & Trichobius tiptoni & 13 & 0.8 \\
Anoura geoffroyi & 3 & $\begin{array}{l}\text { Exastinion clovisi } \\
\text { Strebla harderi }\end{array}$ & 4 & 1.3 \\
Artibeus cinereus & & Trichobius sp. & 1 & 0.3 \\
Artibeus lituratus & 3 & & 0 & 0.3 \\
Artibeus planirostris & 2 & Megistopoda aranea & 2 & 0 \\
Carollia prespicillata & 5 & Trichobius joblingi & 69 & 0.3 \\
Chiroderma doriae & 40 & Strebla guajiro & 1 & 1.4 \\
Desmodus rotundus & 2 & Strebla wiedemanni & 0 & 0 \\
Glossophaga soricina & 20 & & 1 & 0.5 \\
Mimon crenulatum & 4 & Basilia tiptoni & 0 \\
Platyrrhinus lineatus & 48 & Paratrichobius longicrus & 8 & 0 \\
Sturnira lilium & 47 & Aspidoptera falcata & 28 & 1.7 \\
\hline Total & & Megistopoda proxima & 29 & 0.2 \\
\hline
\end{tabular}

$a$ : four of the species had no batflies; $b$ : family Nycteribiidae; all others are Streblidae. 


\section{TABLE II}

Prevalence of batflies by sex and developmental stage of the host, collected on the most abundant Phyllostomid bats from August 1990 to July 1991 at the "Panga" Ecological Reservation, Uberlândia, State of Minas Gerais, Brazil. In parentheses are the number of bats colleted

\begin{tabular}{|c|c|c|c|c|c|c|}
\hline \multirow[b]{2}{*}{$\begin{array}{l}\text { Bat species } \\
\text { Batfly species }\end{array}$} & \multicolumn{6}{|c|}{ Age and reproductive condition of the host } \\
\hline & $\begin{array}{l}\text { Juvenile } \\
\text { Male } \\
\text { Female }\end{array}$ & $\begin{array}{l}\text { Adult } \\
\text { Male } \\
\text { Female }\end{array}$ & $\begin{array}{l}\text { Scrotal } \\
\text { testes } \\
\text { Male }\end{array}$ & $\begin{array}{l}\text { Lactating } \\
\text { Female }\end{array}$ & $\begin{array}{l}\text { Pregnant } \\
\text { Female }\end{array}$ & $\begin{array}{l}\text { Male } \\
\text { Female } \\
\text { GR }\end{array}$ \\
\hline Anoura caudifera & & & & & & \\
\hline Trichobius tiptoni & $\begin{array}{l}0.0(0) \\
0.0(0)\end{array}$ & $\begin{array}{l}50.0(4) \\
50.0(4)\end{array}$ & $\begin{array}{l}40.0 \\
\text { NA }\end{array}$ & $\begin{array}{c}\text { NA } \\
0.0(1)\end{array}$ & $\begin{array}{c}\text { NA } \\
50.0(2)\end{array}$ & $\begin{array}{l}44.0(9) \\
43.0(7) \\
43.75(16)\end{array}$ \\
\hline $\begin{array}{l}\text { Carollia perspicillata } \\
\text { Trichobius joblingi }\end{array}$ & $\begin{array}{l}57.14(7) \\
0.0(1)\end{array}$ & $\begin{array}{l}75.0(12) \\
66.7(18)\end{array}$ & $\begin{array}{c}62.5(8) \\
\text { NA }\end{array}$ & $\begin{array}{c}\text { NA } \\
66.7(3)\end{array}$ & $\begin{array}{l}\mathrm{NA} \\
2.0(1)\end{array}$ & $\begin{array}{l}66.7(27) \\
65.2(23) \\
66.0(50)\end{array}$ \\
\hline $\begin{array}{l}\text { Platyrrhinus lineatus } \\
\quad \text { Paratrichobius longicrus }\end{array}$ & $\begin{array}{l}0.0(0) \\
0.0(0)\end{array}$ & $\begin{array}{r}0.0(13) \\
16.7(12)\end{array}$ & $\begin{array}{l}0.0(4) \\
\text { NA }\end{array}$ & $\begin{array}{c}\text { NA } \\
18.7(16)\end{array}$ & $\begin{array}{l}\text { NA } \\
6.7(3)\end{array}$ & $\begin{array}{l}0.0(17) \\
22.6(31) \\
14.6(48)\end{array}$ \\
\hline $\begin{array}{l}\text { Sturnira lilium } \\
\quad \text { Aspidoptera falcata }\end{array}$ & $\begin{array}{r}100.0(1) \\
55.6(9)\end{array}$ & $\begin{array}{l}10.0(10) \\
46.1(13)\end{array}$ & $\begin{array}{c}33.3(9) \\
\text { NA }\end{array}$ & $\begin{array}{c}\text { NA } \\
33.3(3)\end{array}$ & $\begin{array}{c}\text { NA } \\
50.0(2)\end{array}$ & $\begin{array}{l}25.0(20) \\
48.1(27)\end{array}$ \\
\hline $\begin{array}{l}\text { Sturnira lilium } \\
\quad \text { Megistopoda proxima }\end{array}$ & $\begin{array}{r}100.0(1) \\
55.6(9)\end{array}$ & $\begin{array}{l}30.0(10) \\
30.7(13)\end{array}$ & $\begin{array}{c}0.0(9) \\
\text { NA }\end{array}$ & $\begin{array}{c}\text { NA } \\
66.7(3)\end{array}$ & $\begin{array}{c}\text { NA } \\
50.0(2)\end{array}$ & $\begin{array}{l}20.0(20) \\
34.0(47)\end{array}$ \\
\hline
\end{tabular}

GR: global rate - the prevalence of batflies regardless of bat sex; NA: not applicable.

TABLE III

Parasitism intensity (\%) of batflies by sex and developmental stage of the host, collected on the most abundant Plyllostomid bats at the "Panga" Ecological Reservation, Uberlândia, State of Minas Gerais, Brazil from August 1990 to July 1991

\begin{tabular}{lllllll}
\hline \multirow{2}{*}{$\begin{array}{l}\text { Bat species } \\
\text { Batfly species }\end{array}$} & $\begin{array}{l}\text { Juvenile } \\
\text { Male } \\
\text { Female }\end{array}$ & $\begin{array}{l}\text { Adult } \\
\text { Male } \\
\text { Female }\end{array}$ & $\begin{array}{l}\text { Scrotal } \\
\text { testes } \\
\text { Male }\end{array}$ & $\begin{array}{l}\text { Lactating } \\
\text { Female }\end{array}$ & $\begin{array}{l}\text { Pregnant } \\
\text { Female }\end{array}$ & $\begin{array}{l}\text { Male } \\
\text { Female } \\
\text { GR }\end{array}$ \\
\hline $\begin{array}{l}\text { Anoura caudifera } \\
\text { Trichobius tiptoni }\end{array}$ & 0.0 & 1.0 & 0.6 & NA & NA & 0.8 \\
& 0.0 & 1.2 & NA & 0.0 & 0.5 & 0.9 \\
Carollia perspicillata & & & & & & 0.8 \\
$\quad$ Trichobius joblingi & 1.4 & 2.3 & 0.9 & NA & NA & 1.67 \\
& 0.0 & 0.9 & NA & 1.7 & 2.0 & 1.0 \\
Platyrrhinus lineatus & & & & & & 1.4 \\
$\quad$ Paratrichobius longicrus & 0.0 & 0.0 & 0.0 & NA & NA & 0.0 \\
& 0.0 & 0.2 & NA & 0.2 & 0.7 & 0.3 \\
Sturnira lilium & & & & & & 0.2 \\
Aspidoptera falcata & 1.0 & 0.1 & 0.3 & NA & NA & 0.2 \\
& 1.1 & 0.8 & NA & 0.7 & 0.5 & 0.8 \\
Sturnira lilium & & & & & & 0.6 \\
Megistopoda proxima & 3.0 & 0.4 & 0.0 & NA & NA & 0.3 \\
& 0.9 & 0.7 & NA & 1.3 & 0.5 & 0.8 \\
& & & & & & 0.6 \\
\hline
\end{tabular}

GR: global rate - the intensity of batfly parasitism regardless of bat sex; NA: not applicable. Parasitism intensity by A. falcata was significantly higher for male than for female $S$. lilium $\left(\mathrm{t}_{16}=2.33 ; \mathrm{P}=0.02\right)$. 
for the adult stage (Tables II-IV). No analysis was done due to the low rate of parasitism.

The bat, Sturnira lilium Geoffroy, was parasitized by two species of Streblidae: Aspidoptera falcata Wenzel and Megistopoda proxima (Séguy) (Table I). Both parasites occurred either as single or as mixed species populations on an individual bat. Parasite prevalence, intensity, as well as mean intensity were higher on female hosts (Tables IIIV). For A. falcata, no significant differences in prevalences among all stages of the host were found, but prevalences and mean intensities were significantly different when comparing specific ages or reproductive stages. Parasite intensity for A. falcata was associated with the sex of the host, favoring females, with an average of 1.3 flies per animal, compared with the average of 0.3 flies per male (Table II). In relation to the number of flies per host, the simultaneous presence of $M$. proxima on the same host did not influence any of the rates. However, a significant negative association between M. proxima and A. falcata occurring simultaneously on the same host species $\left(r_{\mathrm{xy}}=-0,43\right.$; $\left.t_{24}=-2,35 ; P<0,05\right)$.
M. proxima was more prevalent on female Sturnira lilium bats. Parasite prevalence and intensity were higher for young females, but parasite mean intensity was higher among adult females. Simultaneous occurrence with A. falcata prevailed among adult female hosts but, as before, no significant differences among rates were found.

The occurrence of Paratrichobius longicrus (Miranda Ribeiro) on Platyrrhinus lineatus (Geoffroy) was low (Table I). Only females were parasitized, with lactating females being more heavily parasitized. The low numbers of collected parasites precluded any further quantitative analysis.

The remaining bat species had very few parasites or were not parasitized. Of the two Desmodus rotundus Geoffroy collected, one was parasitized by two Strebla wiedemannii (Fabricius). Mimon crenulatum Geoffroy, was the only bat species parasitized by the nycteribiid Basilia tiptoni Guimarães. The highest diversity of bat fly ectoparasites occurred on Anoura geoffroyi Gray, that was parasitized by three species. S. lilium and $C$. perspicillata harbored two species (Table I). Unfortunately, the only specimen of Trichobius sp.

\section{TABLE IV}

Parasite mean intensity of the most abundant Phyllostomid bats parasitized by batflies collected at the "Panga" Ecological Reservation, Uberlândia, State of Minas Gerais, Brazil, from August 1990 to July 1991

\begin{tabular}{|c|c|c|c|c|c|c|}
\hline \multirow[b]{2}{*}{$\begin{array}{l}\text { Bat species } \\
\text { Batfly species }\end{array}$} & \multicolumn{6}{|c|}{ Age and reproductive condition of the host } \\
\hline & $\begin{array}{l}\text { Juvenile } \\
\text { Male } \\
\text { Female }\end{array}$ & $\begin{array}{l}\text { Adult } \\
\text { Male } \\
\text { Female }\end{array}$ & $\begin{array}{l}\text { Scrotal } \\
\text { testes } \\
\text { Male }\end{array}$ & $\begin{array}{l}\text { Lactating } \\
\text { Female }\end{array}$ & $\begin{array}{l}\text { Pregnant } \\
\text { Female }\end{array}$ & $\begin{array}{l}\text { Male } \\
\text { Female } \\
\text { GR }\end{array}$ \\
\hline Anoura caudifera & & & & & & \\
\hline Trichobius tiptoni & $\begin{array}{l}0.0 \\
0.0\end{array}$ & $\begin{array}{l}2.0 \\
2.5\end{array}$ & $\begin{array}{r}1.5 \\
\mathrm{NA}\end{array}$ & $\begin{array}{l}\text { NA } \\
0.0\end{array}$ & $\begin{array}{c}\text { NA } \\
1.0\end{array}$ & $\begin{array}{l}1.7 \\
2.0 \\
1.8\end{array}$ \\
\hline $\begin{array}{l}\text { Carollia perspicillata } \\
\text { Trichobius joblingi }\end{array}$ & $\begin{array}{l}2.5 \\
0.0\end{array}$ & $\begin{array}{l}3.1 \\
1.4\end{array}$ & $\begin{array}{l}1.4 \\
\mathrm{NA}\end{array}$ & $\begin{array}{l}\text { NA } \\
2.5\end{array}$ & $\begin{array}{l}\text { NA } \\
2.0\end{array}$ & $\begin{array}{l}2.5 \\
1.6 \\
2.1\end{array}$ \\
\hline $\begin{array}{l}\text { Platyrrhinus lineatus } \\
\quad \text { Paratrichobius longicrus }\end{array}$ & $\begin{array}{l}0.0 \\
0.0\end{array}$ & $\begin{array}{l}0.0 \\
1.0\end{array}$ & $\begin{array}{r}0.0 \\
\mathrm{NA}\end{array}$ & $\begin{array}{l}\text { NA } \\
1.3\end{array}$ & $\begin{array}{c}\text { NA } \\
1.0\end{array}$ & $\begin{array}{l}1.0 \\
1.1 \\
1.1\end{array}$ \\
\hline $\begin{array}{l}\text { Sturnira lilium } \\
\quad \text { Aspidoptera falcata }\end{array}$ & $\begin{array}{l}1.0 \\
2.0\end{array}$ & $\begin{array}{l}1.0 \\
1.7\end{array}$ & $\begin{array}{r}1.0 \\
\mathrm{NA}\end{array}$ & $\begin{array}{l}\text { NA } \\
2.0\end{array}$ & $\begin{array}{c}\text { NA } \\
1.0\end{array}$ & $\begin{array}{l}1.0 \\
1.8 \\
1.6\end{array}$ \\
\hline $\begin{array}{l}\text { Sturnira lilium } \\
\text { Megistopoda proxima }\end{array}$ & $\begin{array}{l}3.0 \\
1.6\end{array}$ & $\begin{array}{l}1.3 \\
2.2\end{array}$ & $\begin{array}{r}0.0 \\
\mathrm{NA}\end{array}$ & $\begin{array}{l}\text { NA } \\
2.0\end{array}$ & $\begin{array}{c}\text { NA } \\
1.0\end{array}$ & $\begin{array}{l}1.7 \\
1.8 \\
1.8\end{array}$ \\
\hline
\end{tabular}

GR: global rate - the mean intensity of batfly parasitism regardless of bat sex; NA: not applicable. Mean intensity of parasitism by $T$. joblingi was significantly higher for male than for female C. perspicillata $\left(\mathrm{t}_{31}=-2.21 ; \mathrm{P}=0.03\right)$. 
collected on A. geoffroyi could not be properly identified due to its poor state of preservation. Of the few Artibeus cinereus, Artibeus lituratus, Chiroderma doriae and Glossophaga soricina collected, none had batflies (Table I).

\section{DISCUSSION}

Bat flies are very active on the host, mainly the winged species of Streblidae, which are able to fly for short distances when disturbed (Marshall 1981). Therefore, the trapping methodology used in this work, by causing at least some winged specimens to fly off the host, could have underestimated the parasite prevalences, intensities as well as mean intensities. In general, the abundances found for species of Streblidae can be considered low in the study area, when compared with the findings of Wenzel (1976) and Fritz (1983). Factors that influence parasitism rates are type of shelter the bat host uses, bat species associations in the shelters and the behavior of hosts and their parasites. Caves are considered favorable shelters for bats and their parasites, for they provide a favorable microclimate. In such habitats, bat colonies, although variable seasonally, may include several hundred individuals (Kunz 1982). This tends to favor the ectoparasites by providing an abundant source of food, high success in dispersal, as well as protection and the favorable conditions of humidity and temperature (Marshall 1981). However, caves do not occur in the study area and this may have forced the bat hosts to seek less favorable roost sites. Therefore, the size of the bat population at each roost could have acted as a factor in limiting the size of the ectoparasite population. Wenzel et al. (1966) suggested that the host must have a population of at least 50 individuals in a shelter in order to be able to maintain a successful population of batflies. This may explain why Streblidae occurred in small numbers or were absent from some hosts. Behavioral factors such as grooming could also limit the numbers of ectoparasites. The primary function of grooming is to rearrange the hair and remove debris, but it also plays a role in removing ectoparasites (Marshall 1981). Another behavioral factor that may play a role in determining the extent of parasitism is that larvipositing females leave the host when it is in the shelter, and this could happen immediately prior to the host leaving the shelter to forage. However, studies of this behavior have not been done.

The occurrence of $T$. joblingi on $C$. perspicillata agrees with the findings of Wenzel (1976), who considers this bat to be the primary host for this fly, and who stated that the occurrence of this batfly on other hosts is incidental. However, based on the numbers reported by Wenzel
(1976) and Fritz (1983) for Central America and Venezuela, the population density of $T$. joblingi in southeastern Brazil is much smaller. The tendency for this species to be collected more often on male bats can be explained by the fact that $C$. perspicillata is gregarious in forming colonies where several harems are formed with few adult males monopolizing the access to the females (Williams 1986), a fact that seems to occur all year. Pregnant females tend to isolate themselves in more exposed conditions, whereas males either remain in the harems or join groups formed by other "single" males. A male may have more than one harem in different shelter sites (Fleming 1988). This author suggested that this behavior of changing shelters by males and the isolation of females in harems may be a way of minimizing the exposure of females to batflies, preventing the offspring from generating heavy parasite loads. In addition, this could be a strategy for reducing or eliminating local populations of batflies because the Streblidae, when off the host, are not resistant to unfavorable environmental conditions. On the other hand, adult male bats that roost in groups become more parasitized than the solitary hosts. This suggest either a behavioral of physiological difference between males.

The specific incidence and infestation rates, as well as parasitic load of $A$. falcata were significantly higher on females of $S$. lilium. This suggests that this bat species is gregarious, with females being predominant in shelters that would function as sites of reproduction and for tending the offspring. The preference for young females could be due to behavioral or physiological factors, or both, of the host. Young females may be less active, causing little disturbance for the parasite. In addition, their epidermis is thinner favoring blood feeding by the batflies (Marshall 1981). On reaching sexual maturity, the females disperse to join new colonies, thereby dispersing their parasites.

M. proxima did not show any significant preference for sex or developmental stage for S. lilium, suggesting that this fly is more flexible in its morphological/physiological requirements. However, the significant negative correlation between this species and A. falcata suggests that the presence of one species on the host may make it difficult for the other to colonize. From an evolutionary perspective, this could be the result of competition between these two species, or a mechanism to keep the numbers of ectoparasites within tolerable limits for the host.

The absence of Streblidae on Glossophaga soricina Pallas may be due to the small sample size. However, this bat is highly active and easily dis- 
turbed when roosting (Trajano 1984). It is known that Streblidae tend to leave active hosts (Marshall 1981).

The association of the batfly $P$. longicrus with $P$. lineatus may be facultative or contaminant, for this bat has habits and shelters similar to those of Artibeus lituratus Olfers (Sazima et al. 1994), which is considered to be the natural host for $P$. longicrus (Wenzel \& Tipton 1966).

The associations between A. caudifera, A. geoffroyi and $D$. rotundus and their parasites agree with the findings of Wenzel et al. (1966) and Wenzel (1976). The occurrence of B. tiptoni on $M$. crenulatum was previously known for the Neotropical region (Guimarães 1966, 1972). Mimon and Anthorhina are the only genera of Phyllostomidae that are parasitized by Nycteribiidae, possibly due to their habit of seeking shelter in sites not favorable for Streblidae (Wenzel et al. 1966).

\section{ACKNOWLEDGEMENTS}

To Dr Lindolpho R Guimarães for help with identification of the batflies; Dr Valdir A Taddei and Wagner A Pedro for help with identification of the bats. The identification of the bats and their parasites made this work possible; Dr Sérgio F dos Reis and Dr Ivan Sazima for useful comments on the manuscript.

\section{REFERENCES}

Araújo GM, Schiavini I 1989. Considerações sobre a vegetação da Reserva Ecológica do Panga (Uberlândia). Sociedade \& Natureza 1: 61-66.

Fleming TH 1988. The Short-tailed Fruit Bat: A Study in Plant-animal Interactions, The University of Chicago Press, Chicago, IL, 363 pp.

Fritz GN 1983. Biology and ecology of batflies (Diptera: Streblidae) on bats in the genus Carollia. J Med Entomol 20: 1-10.

Guimarães LR 1966. Nycteribiid batflies from Panama (Diptera: Nycteribiidae), p. 393-404. In RL Wenzel $\&$ VJ Tipton (eds), Ectoparasites of Panama, Field Museum of Natural History, Chicago, IL.
Guimarães LR 1972. Nycteribiid batflies from Venezuela. Brigham Young University Sci Bull, Biol Series 17: 1-11.

Kunz TH 1982. Roosting ecology, p. 1-55. In TH Kunz, Ecology of Bats, Plenum Press, NY.

Machado-Allison CE 1967. The systematic position of the Desmodus and Chylonycteris, based on host-parasite relationships (Mammalia; Chiroptera). Proc Biol Soc Washington 80: 223-226.

Margolis L, Esch GW, Holmes JC, Kuris AM, Schad GA 1982. The use of ecological terms in parasitology (Report of an ad hoc committee of the American Society of Parasitologists). J Parasitol 68: 131133.

Marshall AG 1981. The Ecology of Ectoparasitc Insects, Academic Press, London, $459 \mathrm{pp}$.

Ross A 1961. Biological studies on bat ectoparasites of the Genus Trichobius (Diptera: Streblidae) in North America, north of Mexico. Wasmann J Biol 19: 229. 246.

Sazima I, Fisher WA, Sazima M, Fisher EA 1994. The fruit bat Artibeus lituratus as a forest and city dweller. Cie Cult 46: 164-168.

SAS Institute Inc 1986. SAS User's Guide: Statistics, Version 6th, Cary, North Carolina.

Trajano E 1984. Ecologia das populações de morcegos cavernícolas em uma região cárstica do Sudeste do Brasil. Rev Bras Zool 2: 255-320.

Wenzel RL 1976. The Streblidae Batflies of Venezuela (Diptera: Streblidae), Bringham Young University Science Bulletin, 172 pp.

Wenzel RL, Tipton VJ 1966. Some relationships between mammal hosts and their ectoparasites, p. 677-723. In RL Wenzel \& VJ Tipton (eds), Ectoparasites of Panama, Field Museum of Natural History, Chicago, IL.

Wenzel RL, Tipton VJ, Kiewlicz A 1966. The streblid batflies of Panama (Diptera: Streblidae), p. 405-675. In Wenzel R \& Tipton VJ (eds), Ectoparasites of Panama, Field Museum of Natural History, Chicago, IL.

Williams CF 1986. Social organization of the bat Carollia perspicillata (Chiroptera: Phyllostomidae). Ethology 71: 265-282. 